\title{
Pesticides in Ground Water - Goshen County, Wyoming, 1995
}

In 1991, members of local, State, and Federal governments, as well as industry and interest groups formed the Ground-water and Pesticide Strategy Committee to prepare the State of Wyoming's generic Management Plan for Pesticides in Ground Water (SMP). Part of this management plan is to sample and analyze Wyoming's ground water for pesticides. In 1995, the U.S. Geological Survey, in cooperation with the Ground-water and Pesticide Strategy Committee, began implementation of the SMP by Sampling wells in Goshen County, Wyoming.

\section{PESTICIDES IN GROUND WATER}

Synthetic organic pesticides are used to control weeds, insects, and other organisms in a wide variety of agricultural and nonagricultural settings. The use of pesticides has helped to make the United States the largest producer provided other benefits, but the use has also been accompanied by of food in the world and has

concerns about their potential adverse effects on the environment and human health. A potential pathway for adverse effects of pesticides is through hydrologic systems, which supply water for both humans and natural ecosystems. Water is one of the primary ways pesticides are transported from an application area to other locations in the environment (fig. 1).

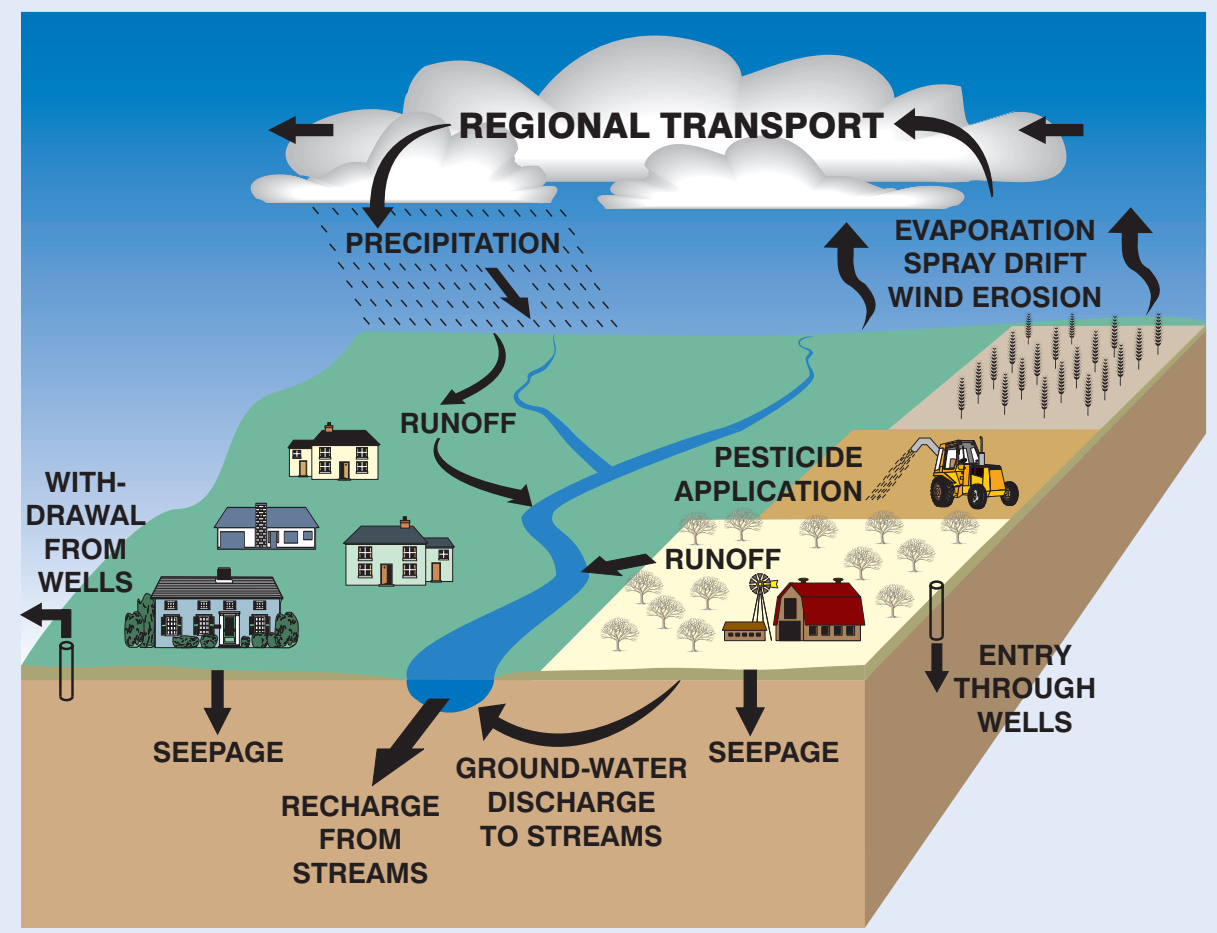

Pesticide contamination of ground water is a national issue because ground water is used for drinking water by about 50 percent of the Nation's population. Concern about pesticides in ground water is especially acute in rural agricultural areas where over 95 percent of the population relies upon ground water for drinking water.

\section{WYOMING'S PESTICIDE MANAGEMENT PLAN}

In 1991, the Ground-water and Pesticide Strategy Committee (GPSC) began developing the generic State Management Plan for Pesticides in Ground Water for the State of Wyoming. The SMP will be required by the U.S. Environmental Protection Agency (EPA) in order for individuals to continue using certain pesticides in Wyoming. The SMP includes information relating to agencies and individuals involved with the implementation of the SMP, ground-water monitoring, methods of preventing ground-water contamination, and what the responses will be to detections of pesticides in ground water.

Figure 1. Pathways of pesticide movement in the hydrologic cycle (modified from U.S. Geological Survey Fact Sheet FS-244-95). 
Table 1. Baseline monitoring for pesticides in Goshen County, 1995.

[ $\mu \mathrm{g} / \mathrm{L}$, micrograms per liter; NE, not established]

\begin{tabular}{|c|c|c|c|c|c|}
\hline Pesticide & $\begin{array}{l}\text { Number } \\
\text { detected/ } \\
\text { Number } \\
\text { sampled }\end{array}$ & $\begin{array}{l}\text { Minimum } \\
\text { reporting } \\
\text { limit } \\
(\mu \mathrm{g} / L)\end{array}$ & $\begin{array}{c}\text { Maximum } \\
\text { concentration } \\
(\mu \mathrm{g} / \mathrm{L})\end{array}$ & $\begin{array}{c}\text { Average } \\
\text { detection } \\
(\mu \mathrm{g} / \mathrm{L})\end{array}$ & $\begin{array}{c}\text { Wyoming } \\
\text { Ground-water } \\
\text { Quality Standard } \\
(\mu \mathbf{g} / L)\end{array}$ \\
\hline \multicolumn{6}{|c|}{ Focal pesticides detected in Goshen County ground water } \\
\hline Atrazine & $29 / 50$ & 0.05 & 0.90 & 0.15 & 3 \\
\hline Cyanazine & $2 / 48$ & 0.200 & 0.130 & 0.07 & 0.9 \\
\hline Hexazinone & $2 / 50$ & 0.05 & 0.05 & 0.05 & 1,065 \\
\hline Simazine & $4 / 50$ & 0.058 & 0.020 & 0.014 & 4 \\
\hline \multicolumn{6}{|c|}{ Non-focal pesticides detected in Goshen County ground water } \\
\hline Diazinon & $1 / 48$ & 0.008 & 0.016 & 0.016 & $\mathrm{NE}$ \\
\hline Prometon & $13 / 50$ & 0.058 & 0.400 & 0.24 & NE \\
\hline
\end{tabular}

\begin{tabular}{|c|c|c|c|c|c|}
\hline \multicolumn{6}{|c|}{ Focal pesticides not detected in Goshen County ground water } \\
\hline Alachlor & Aldicarb & Aldicarb Sulfone $^{1}$ & Aldicarb Sulfoxide ${ }^{1}$ & Bromacil & Clopylarid \\
\hline 2,4-D & DCPA & Dicamba & Difenzoquat $^{2}$ & Metolachlor & Metribuzin \\
\hline Metsulfuron ${ }^{2}$ & Picloram & Tebuthiuron & Telone & & \\
\hline
\end{tabular}

${ }^{1}$ Degradation of product of Aldicarb.

${ }^{2}$ No method of analysis available.

One critical part of the SMP is ground-water monitoring. The ground-water sampling program has two phases. The first phase involves baseline monitoring, which is an initial survey of the pesticides found in a county's ground water. The second phase is problem identification monitoring, which is used to gather more information about the ground water near wells with significant pesticide detections.

Baseline monitoring is directed by a county rank and the vulnerability of the ground water to pesticides. During the development of the SMP, the GPSC evaluated each county in Wyoming to determine the potential vulnerability of the county's ground water to pesticides. Each county was ranked based on the extent of cropland and urban areas in the county, as well as the amount of pesticides sold within the county in 1991.

A ground-water vulnerability map, a summation of seven maps describing the hydrogeology and land use, is used to assist in the selection of monitoring sites in each county. The monitoring focuses on areas where the ground water is most vulnerable.

The GPSC selected 18 pesticides of focus and 2 degradation products to be sampled as part of the SMP (table 1). Ground water from all wells in the baseline monitoring program were analyzed for the pesticides listed in table 1, with the exception of Difenzoquat and Metsulfuron.

\section{GROUND-WATER MONITORING IN GOSHEN COUNTY}

The ground-water sampling part of the SMP began in 1995. The goal of the sampling program is to collect ground-water samples for pesticide analyses in all 23 Wyoming counties. Although the

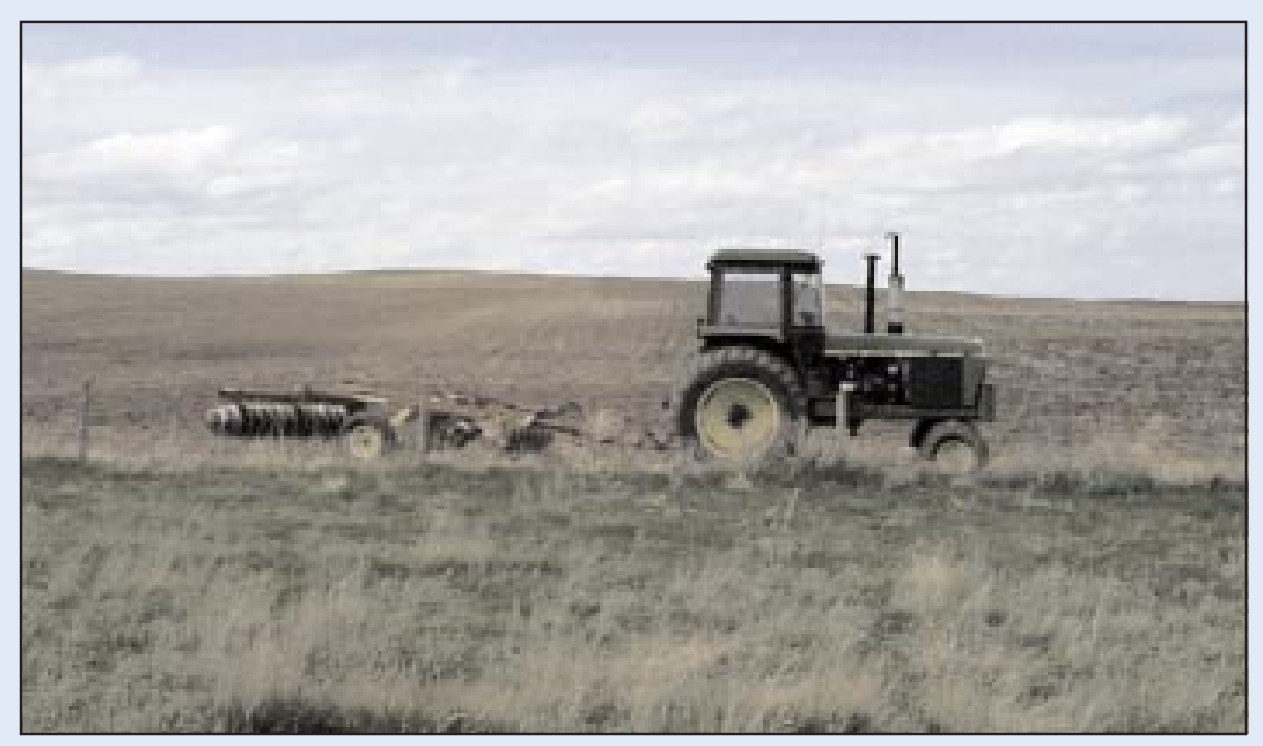


vulnerability of ground water in Goshen County was ranked third in the State, the county was chosen as the first county to monitor because the ground-water vulnerability map had been completed.

The map for Goshen County (fig. 2) was created by the Wyoming Water Research Center. The shallow alluvial aquifers were identified as the most vulnerable to pesticide contamination in Goshen County.

Twenty-five sites were selected for sampling in Goshen County as part of the baseline monitoring program. All wells were selected in areas with the two most vulnerable rankings (areas in red and yellow). The wells were inspected and selected with assistance from the three Goshen County Conservation Districts. All sites were sampled twice during 1995, in the spring and late summer. These two time periods corresponded to low and high water-table conditions.

All levels of pesticides detected in Goshen County wells (table 1) were less than half the safe drinking water standard or its equivalent established by the Wyoming Department of Environmental Quality for municipal supplies (Wyoming Department of Environmental Quality, 1993). Although these standards do not apply to private domestic wells, they do provide a reference as to the acceptable amount of chemicals in drinking water. At least one pesticide was detected in samples from 18 of the 25 wells sampled in Goshen County during 1995 (fig. 3). More than 50 percent of the detections were trace quantities. A trace quantity indicates the pesticide was detected, but at a level too small to quantify. Atrazine was the most commonly detected pesticide, detected in 29 samples from 15 of the 25 wells.
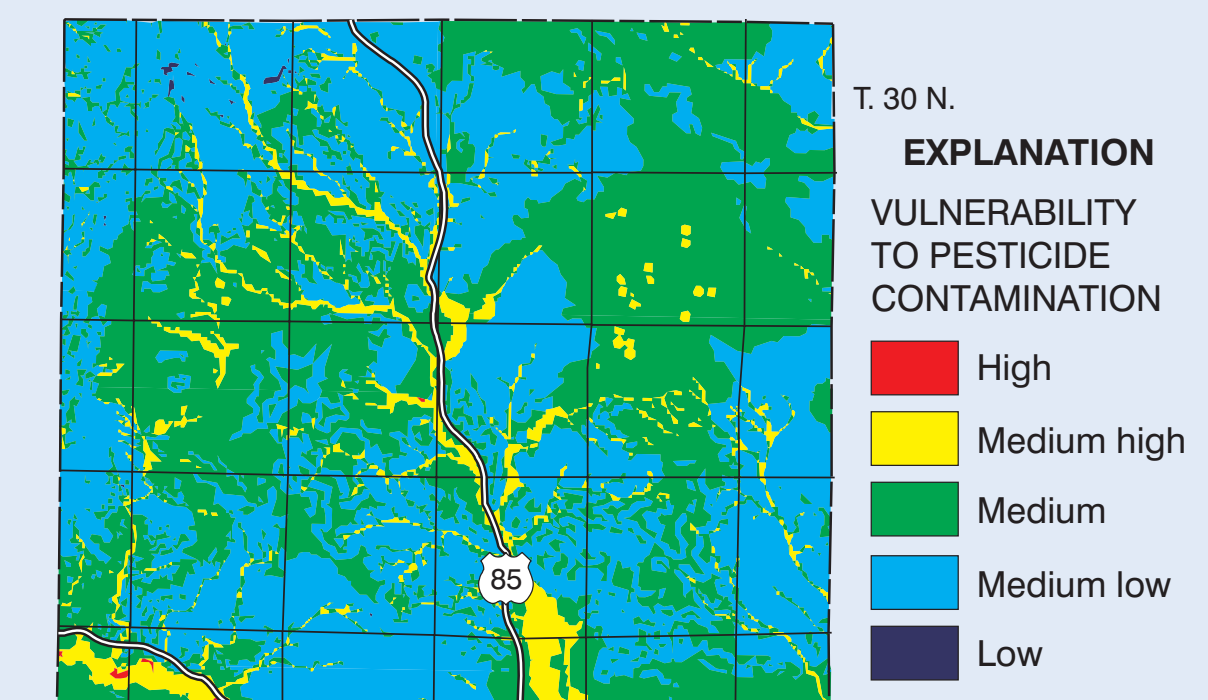

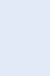


Counties began in 1997. Results of these analyses are available from the U.S Geological Survey in Cheyenne, or the Wyoming Water Research Center in Laramie.

-Prepared by Cheryl A. Eddy-Miller

\section{REFERENCES:}

Wyoming Department of Environmental Quality, 1993, Water quality rules and regulations, chapter VIII, State of Wyoming, 13 p.

U.S. Geological Survey, 1995, Pesticides in ground water: U.S. Geological Survey Fact Sheet FS-244-95, 4 p.

\section{FOR MORE INFORMATION, CONTACT:}

Jim Bigelow

Wyoming Department of Agriculture 2219 Carey Avenue

Cheyenne, Wyoming 82002

(307) 777-7324

Kevin Frederick

Wyoming Department of Environmental Quality, Water Quality Division 4th Floor, Herschler Building Cheyenne, Wyoming 82002

(307) 777-7781

\section{District Chief}

U.S. Geological Survey, WRD 2617 E. Lincolnway, Suite B Cheyenne, Wyoming 82001 (307) 778-2931

\section{Email:}

staterep_wy@mailcheyenne.cr.usgs.gov Internet:

http://wyoming.usgs.gov/welcome.html

This document was prepared by the U.S. Geological Survey (USGS), the Wyoming Department of Agriculture (WDA), and the Wyoming Department of Environmental Quality, Water Quality Division (WDEQ). All agencies are members of the GroundWater and Pesticide Strategy Committee.

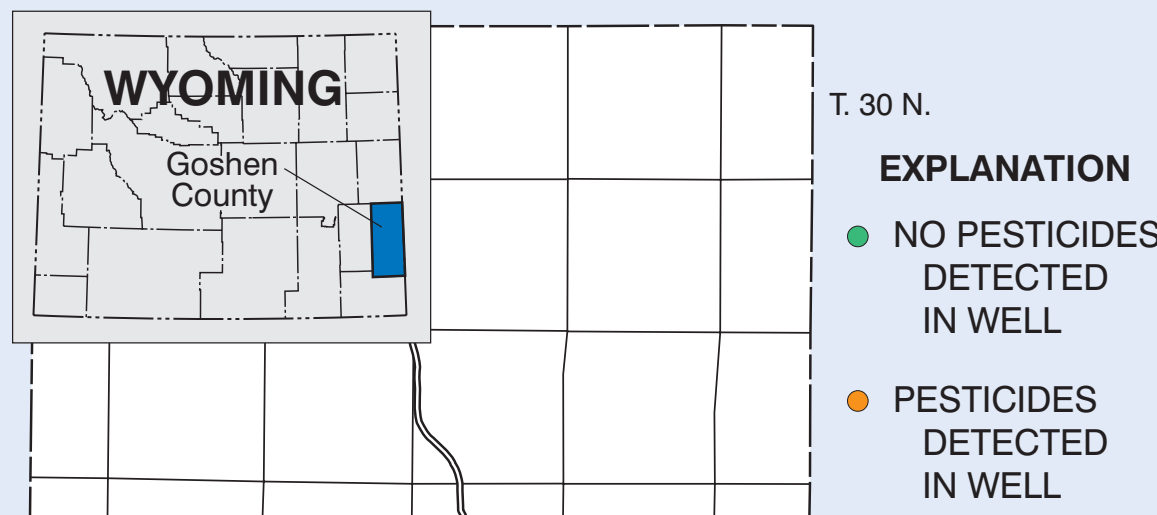

The use of trade, product, industry, or firm names is for descriptive purposes only and does not imply endorsement by the U.S. Government. 